Springer Tracts in Civil Engineering

Cristiana Bartolomei Alfonso Ippolito

Simone Helena Tanoue Vizioli Editors
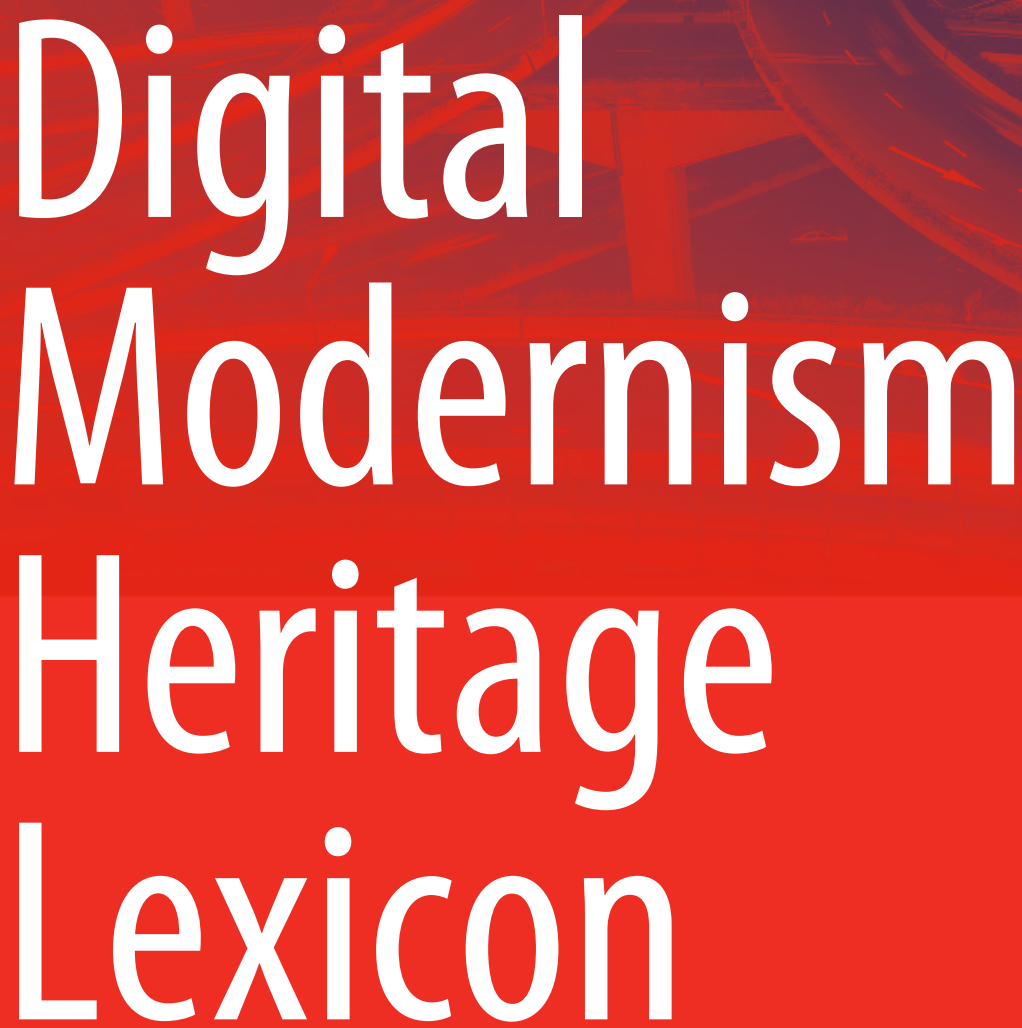

Springer 


\section{Springer Tracts in Civil Engineering}

\section{Series Editors}

Giovanni Solari, Wind Engineering and Structural Dynamics Research Group, University of Genoa, Genova, Italy

Sheng-Hong Chen, School of Water Resources and Hydropower Engineering, Wuhan University, Wuhan, China

Marco di Prisco, Politecnico di Milano, Milano, Italy

Ioannis Vayas, Institute of Steel Structures, National Technical University of Athens, Athens, Greece 
Springer Tracts in Civil Engineering (STCE) publishes the latest developments in Civil Engineering - quickly, informally and in top quality. The series scope includes monographs, professional books, graduate textbooks and edited volumes, as well as outstanding $\mathrm{PhD}$ theses. Its goal is to cover all the main branches of civil engineering, both theoretical and applied, including:

- Construction and Structural Mechanics

- Building Materials

- Concrete, Steel and Timber Structures

- Geotechnical Engineering

- Earthquake Engineering

- Coastal Engineering; Ocean and Offshore Engineering

- Hydraulics, Hydrology and Water Resources Engineering

- Environmental Engineering and Sustainability

- Structural Health and Monitoring

- Surveying and Geographical Information Systems

- Heating, Ventilation and Air Conditioning (HVAC)

- Transportation and Traffic

- Risk Analysis

- Safety and Security

\section{Indexed by Scopus}

To submit a proposal or request further information, please contact:

Pierpaolo Riva at Pierpaolo.Riva@springer.com (Europe and Americas) Wayne Hu at wayne.hu@springer.com (China)

More information about this series at http://www.springer.com/series/15088 
Cristiana Bartolomei - Alfonso Ippolito · Simone Helena Tanoue Vizioli

Editors

\section{Digital Modernism Heritage Lexicon}

粤 Springer 


\section{Editors}

\author{
Cristiana Bartolomei \\ Department of Architecture \\ University of Bologna \\ Bologna, Italy
}

\author{
Simone Helena Tanoue Vizioli (D) \\ Architecture and Urbanism Institute \\ Universidade de São Paulo \\ São Paulo, Brazil
}

\author{
Alfonso Ippolito \\ DSDRA \\ Sapienza University of Rome \\ Rome, Italy
}

\author{
ISSN 2366-259X \\ ISSN 2366-2603 (electronic) \\ Springer Tracts in Civil Engineering \\ ISBN 978-3-030-76238-4 \\ ISBN 978-3-030-76239-1 (eBook) \\ https://doi.org/10.1007/978-3-030-76239-1
}

(C) The Editor(s) (if applicable) and The Author(s), under exclusive license to Springer Nature

Switzerland AG 2022

This work is subject to copyright. All rights are solely and exclusively licensed by the Publisher, whether the whole or part of the material is concerned, specifically the rights of translation, reprinting, reuse of illustrations, recitation, broadcasting, reproduction on microfilms or in any other physical way, and transmission or information storage and retrieval, electronic adaptation, computer software, or by similar or dissimilar methodology now known or hereafter developed.

The use of general descriptive names, registered names, trademarks, service marks, etc. in this publication does not imply, even in the absence of a specific statement, that such names are exempt from the relevant protective laws and regulations and therefore free for general use.

The publisher, the authors and the editors are safe to assume that the advice and information in this book are believed to be true and accurate at the date of publication. Neither the publisher nor the authors or the editors give a warranty, expressed or implied, with respect to the material contained herein or for any errors or omissions that may have been made. The publisher remains neutral with regard to jurisdictional claims in published maps and institutional affiliations.

This Springer imprint is published by the registered company Springer Nature Switzerland AG The registered company address is: Gewerbestrasse 11, 6330 Cham, Switzerland 


\section{Preface}

In order to define the art of Architecture the text "Eupalinos ou O Arquiteto" by Paul Valery (1996) was chosen. Such text brings a discussion between Socrates and Fedro, his disciple, whose shadows are confined in the land of the dead. In this scenario, Fedro resumes a conversation he had with his friend Eupalinos, the architect of Aqueducts and the Temple of Hermes, in which Eupalinos makes a comparison between two forms of art-Architecture and Music. He divides buildings between those which are silent, those which speak, and those which sing. For him, the buildings that neither speak nor sing deserve only disdain; they are dead things, they are nothing but piles of stones dumped by the contractors' wagons. Monuments that limit themselves to speaking, if they do so clearly, deserve attention; they are able to gather merchants, allow judges to deliberate, welcome the groans of prisoners [...] merchant galleries, courts, and prisons, when well built, have the clearest language. However, Eupalinos highlights those buildings of unique art-the buildings that sing- "The most beautiful aspect of Architecture lives in them because it presents itself not only as the building that imposes itself against nature but as the building that imposes itself against the man, as he is, as in tragedies. A building made of choice, of the freedom to choose [...] designed in the deepest encounter with oneself" (Valery, 1996, p. 57, editors version) [1]. The singing buildings reveal the various faces of the soul, where their strengths and graces are tamed by the constructive act.

Thus, this book aims to investigate some lexicons that represent, compose and define the "singing buildings" of Modern Architecture. For this, it uses not only the study of Cultural Heritage that aims to identify, document, and preserve the memory of the past and the value of the future, but also the current digital technologies that have made it possible to register and evaluate the transformations of historic buildings marked by the action of time.

It is undeniable that the relationship between man and the object has been changed significantly in recent decades and it is not different in relation to graphic language and representation. According to Flusser (2008) [2], the first traces of historical records were sculpted in stones, a relationship between man and tool, a record of memory in which the man is the subject of the world. Later, the man discovered ways to transfer the real world to paper and perfected it with the invention of perspective 
drawing; the registration of the works was largely executed through reproductions and drawings that were able to reveal different contexts - this is the relationship between man and the machine. From then on, the man felt the need to explain his visions conceptually, then he looked at the processes inaugurating the relationship between the man and the computer. Today, we live in the digital world of pressing computer keys. In historical and technological evolution, it is necessary to define not only the role of the machine but also the role of the man. Man has gone through great revolutions and today we are experiencing the Digital Revolution, which has brought changes in society and in its way of life.

Therefore, this book seeks to combine this digital moment with the documentation of history, revisiting Modernism (1920-1960 and epigones), its paths and legacies, equipped with new tools and new perspectives.

Modern architecture was born in a context of technical, social, and cultural changes linked to the Industrial Revolution. The strong demographic growth of Europe in the 19th century gave rise to major urban transformations, among them the rapid industrialization process of European cities that resulted in population displacement to large cities. The Industrial Revolution was largely responsible for the emergence of the movement that influenced art, literature, cinema, design, and architecture. New materials produced on a large scale, such as iron, glass, steel, and reinforced concrete, came to be used and allowed architects to create structurally distinct buildings. Concomitantly with new technological discoveries, the social function of architecture has always been part of the modern debate; they aimed at building a New World and breaking away from traditional spatial conceptions.

From this context, the goal of this book was to investigate the modernist lexicon, 100 years after its birth, expressed not only in the field of architecture and engineering but also in all areas where it can be reread in a current and meaningful view, which ranges from aesthetic introspection to anti-technological reactions, through works by thinkers and artists ranging from Nietzsche to Gropius.

The task in delineating the themes that compose this book is not easy due to the interesting approaches that transit through the tangible and intangible heritage of modernism, passing through its history, its constructive processes, its hybrid building mixing tradition and modernity. The book presents Modern Architecture and its representations, conservation, restoration, the documentation of this cultural heritage, and the drawing of the urban space and the facades of the public spaces.

The chapters include contributions from different countries, Argentina, Australia, Brazil, Colombia, Greece, Italy, Spain, Catalonia, and the USA. The texts go through conceptual discussions about the modernist movement, about the meaning of the manufacture of the modern period and the digital age - they explore the process from vernacular architecture to the issue of innovative materials for Architecture and Engineering, such as steel, reinforced concrete, oxidized aluminum, among others. It encompasses analyses from the scale of urban furniture to bridges and tall buildings; from urban to rural places. It also brings studies developed from 3D digital mappings, analyses, and reflections on architectural heritage through 2D and 3D digital models, digitization, and HBIM. Technologies include photogrammetry, laser 
scanning, registration based on the GIS (Geographic Information System) methodology. Includes studies on reference architects such as Walter Gropius, Mies Van der Rohe, and Le Corbusier and some highlights of Modern Architecture in Brazil, among them Vilanova Artigas, Oscar Niemeyer, Lina Bo Bardi, and Rino Levi. The chapters present other important Italian architects such as Marcello Piacentini, Luigi Moretti, Giuseppe Vaccaro, William Pereira, Maurizio Sacripanti, and Giovanni Michelucci.

All in all, this book is expected to support the study of Cultural Heritage: from different forms of art to architecture, from design to engineering, from literature to history, as representation as well as restoration, and as contributions to an international approach to the handling of this cultural heritage.

Bologna, Italy

Rome, Italy

São Paulo, Brazil
Cristiana Bartolomei

Alfonso Ippolito

Simone Helena Tanoue Vizioli

\section{References}

[1] Valéry P (1996) Eupalinos ou L'Architecte. Tradução de Olga Reggiani. Rio de Janeiro: Ed. 34

[2] Flusser V (2008) O universo das imagens técnicas: elogio da superficialidade. São Paulo: Anablume 


\section{Contents}

Steel and Architecture: Analysis of Some Singular Italian

Experiments of the Sixties of the Last Century

Marcello Zordan

Modernism/Modernisms. The Two Souls of Modernity Before

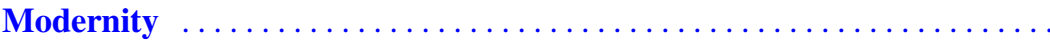

Enrico Cicalò and Michele Valentino

The Brazilian 20th Century's Houses. Digital Documentation

for Preservation and Enhancement of Modernist Architecture

and Design Processes

Marcello Balzani and Luca Rossato

Between the Layers. Transparent Paper as a Modernist

Architectural Design Environment

Fabio Colonnese

Tamed Tropics: Modern Architecture in the Colombian

Caribbean

Massimo Leserri, Merwan Chaverra Suárez, and Pedro Martínez Osorio

Blossoming of a Modernist Lexicon. Camillo Autore

and the Reconstruction of Reggio Calabria

Daniele Colistra and Francesco De Lorenzo

The Missing Piece. Luigi Moretti's Shrine to the Martyrs

of the Fascist Revolution at the Foro Mussolini, Rome

Marco Giunta and Fabio Colonnese

“Case del Fascio": Forgotten 'Fragments' in Contemporary

Rome

Marina Docci 
The New Astronomical Observatory of Rome. A Philological Reinterpretation of an Unfinished and Monumental Modern Complex

Arturo Gallozzi and Rodolfo Maria Strollo

Mediterranean Islands' Vernacular Architecture and the Origin of Modern Architecture

Pedro Miguel Jiménez-Vicario, María Mestre-Martí, and Manuel Alejandro Ródenas-López

Modern Construction in Bologna. The Faculty of Engineering by Giuseppe Vaccaro, 1932-1935

Giorgia Predari, Davide Prati, and Angelo Massafra

The Church of Cristo Re in Cagliari, 1952-1963, G. Genta and S. Panzarasa: Tradition and Modernity in the Architecture of the Central Sacred Space

Andrés Martínez-Medina, Vincenzo Bagnolo, and Andrea Pirinu

Bari Discovering Dioguardi. Possible Strategies for Reading the Built Work of Saverio Dioguardi

Valentina Castagnolo and Anna Christiana Maiorano

From the Office Skyscraper to the Residential Tower: The Case of the Vistamar Tower in Alicante, 1962-1965

Justo Oliva-Meyer, Andrés Martínez-Medina, and Marco Lucchini

Architecture and a Systematic Approach as Amplification of the Modern Project Lexicon. Modernist Experiences in Argentina Around the 1960s

Luis Müller and Cecilia Parera

Elaboration of a Critical Paradigm for Interpreting Modern

Architecture: The Almost Intangible Essence of Luigi Moretti's

Casa del Balilla at Trecate

Salvatore Damiano and Eleonora Di Mauro

Historical-Graphic Introspection on Catalan Modernism the Architectural Lexicon of Agricultural Structures . . . . . . . . . . . .

Caterina Palestini and Carlos Cacciavillani

Icons of the Italian Style. The Façade of Olivetti Headquarters

Building in Milan (1954)

Anna Chiara Benedetti, Carlo Costantino, and Riccardo Gulli

Mutant Bodies. Statue Digitization and Exhibition at the National Archaeological Museum of Venice

Massimiliano Ciammaichella and Gabriella Liva 
Structural Lexicon. Expressiveness of Steel Grids in Italian

Urban Contexts

Renato Morganti, Alessandra Tosone, Danilo Di Donato, and Matteo Abita

The E-1027, That Obscure Object of Design

Carlos L. Marcos and Michael Swisher

The Pavillon de l'Esprit Nouveau of Le Corbusier. From Real

Scale Replica to Digital Modelling and Environmental Analysis

Luca Guardigli, Maria Beatrice Bettazzi, Cecilia Mazzoli, and Giovanni Semprini

Digital Heritage Interpretation of Modernist Modular

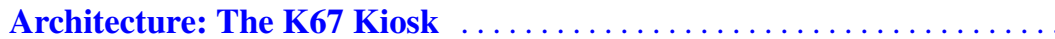

Kaja Antlej

For "A Positive and Feasible Architecture". The Contribution of Mario Chiattone to the Avant-Garde Movements of the Early

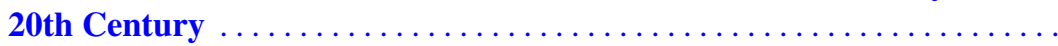

Denise Ulivieri, Marco Giorgio Bevilacqua, Mattia Patti, and Alessia Domenichini

The Contribution of "Local" Registers to the Census of the Modern Movement. A GIS Solution Being Created

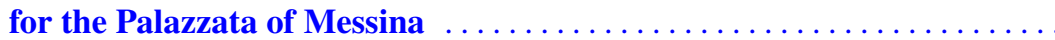

Alessandra Cernaro and Luis M. Palmero Iglesias

Theory and Practice of the Architectural Project at VChUTEMAS. Graphic Interpretations

Starlight Vattano

Dance and Architecture. Representations. Surveying

the Geographies of Space

Antonella Salucci and Eleonora Giancristofaro

Learning Through Models: Sapienza Campus in Six Shots

Martina Attenni, Carlo Bianchini, Marika Griffo, Carlo Inglese, and Alfonso Ippolito

The Modernist Culture of Building Materials in Umbria

Fabio Bianconi, Raffaele Federici, and Marco Filippucci

The Geisel Library, the Brutalist Architecture of William Pereira . . . .

Cristiana Bartolomei, Falko Kuester, Eric Lo, Caterina Morganti, and Dominique Rissolo

Auditoriums in Oscar Niemeyer's Architecture: Strategies and Persistence of the Concept of Plasticity

Wilson Florio and Ana Tagliari 
Comparative Lexicology of a Built Cultural Heritage. The

Curutchet House in La Plata Designed by Le Corbusier

Fabiana Carbonari, Emanuela Chiavoni, and Michela Cigola

Sacripanti Unbuilt. Icons of Modernity

Francesco Maggio and Giulia Raspanti

H-BIM Modelling for Enhancing Modernism Architectural Archives. Reliability of Reconstructive Modelling for "on Paper" Architecture

Roberta Spallone and Fabrizio Natta

Modern Architecture Seeds Spread on Brazilian Soil: Ginásio

de Itanhaém-The Embodied Work

Gabriel Braulio Botasso and Simone Helena Tanoue Vizioli

Post-war Modernism in Greece: The "XENIA" Construction

Program for an Architecture of Tourism During the 50s-60s . . . . . . .

Anastasia Fotopoulou, Alice Monacelli, and Annarita Ferrante

The Neural Network Model for a Multimedia Reinterpretation of the Modern Movement. The Representation of Transversal and Coherent Relationships in the Artistic and Architectural Productions of the De Stijl Movement

Agostino Urso and Francesco De Lorenzo

Collaboration Between Architects and Companies

in the Development of a Modern Architecture Lexicon:

Bombelli's Technological Systems

Daniela Bosia, Tanja Marzi, Lorenzo Savio, and Virginia Bombelli

Digital Reconstruction of Unbuilt Architectures: Sergio Hutter's

Design for the Euro-Kursaal in San Sebastian, Spain . . . . . . . . . . . .

Marco Vitali, Giulia Bertola, and Francesca Ronco

From the Survey to the Digital Construction Site

Adriana Rossi and Umberto Palmieri

Paul Rudolph's Construction: Material and Space . . . . . . . . . . . .

Noelia Cervero Sánchez

Design Systems of Modern Architecture as a Tool for the Re-use and Restoration Project. The School of Engineering in Bologna

by Giuseppe Vaccaro

Luca Cipriani and Silvia Bertacchi

Ralph Erskine. The Artic Architect of Modernism 
Design Strategies in Vilanova Artigas' Architecture and the Essential Role of the Vertical Section

Ana Tagliari and Wilson Florio

Virtual Modernisms. A Digital Investigation on Enrico

Castiglioni Structures

Ilaria Giannetti and Claudio Intrigila

Marcello Piacentini, Genesis of a Form: The Drawing of the University City of Rome by "La Sapienza"

Luca Ribichini and Lorenzo Tarquini

Monoscopic Photogrammetry to Investigate the Buildings

in the Period of Modernism in Salerno: The Case Study

of Torquato Tasso High School

Sara Morena and Simona Talenti

The Edge of Modernist 'sventramento' at Piazza Augusto

Imperatore in Rome

Matteo Flavio Mancini and Sofia Menconero

Modern Architecture, Plano de Ação, and Social Role

of Architecture ...........................

Eduardo Galbes Breda de Lima, Jasmine Luiza Souza Silva,

Júlia Simabukuro, Miranda Zamberlan Nedel, and Rachel Bergantin

Peripheral Architectural Hierophanies. Claudio Caveri's Sacred

Architecture

María Lourdes de la Fuente

Architectural Transformations in Downtown São Paulo

in the 1940s, 1950s, and 1960s

Luiza Paes de Barros Camara de Lucia Beltramini, Márcio Cotrim, and Paulo César Castral

The Reasons of a Form: Project Drawings of the Ridolfi Group

for the Competition "Palazzo del Littorio" in Rome . . . . . . . . . . . . . . . 1201

Emanuela Chiavoni and Federico Rebecchini

Maison Particulière. Graphic Reading and Virtual

Reconstruction ..................................... 1223

Vincenza Garofalo and Marco Di Bella

Raffaello Fagnoni and the School of Aeronautical

Application-School of Air War in Florence Architecture

of a Controversial and Damaged Past

Marco Ricciarini 
E1: Industrialization in Modern Brazilian Architecture, 1950

Ana Lúcia Cerávolo, Ana Regina Mizrahy Cuperschmid,

Felipe Bruno Lima da Silva, and Márcio Minto Fabricio

Conceptual Matrices Between Modern Art and Architectural

Representation Models in Modern(isms), and Beyond. A Study

Based on the Architecture of Zaha Hadid

Adriana Ricciardi Rodrigues Lima and Rafael Antonio Cunha Perrone

Developing Critical Knowledge of Twentieth-Century Cultural

Heritage via Massive Survey: The Case of the Conservation

Plan of the Stadio Flaminio in Rome

Alekos Diacodimitri, Maurizio Giodice, Francesco Romeo, and Marco Balsi

The Spanish Neo-Colonial Architecture: The Other Western

Architectural Option to Build Modernity

Antonio Gómez Gil and María Mestre Martí

The Time Variable in the Communication of Memory: New

Models to Portray the Former GIL Building Designed by Luigi

Moretti

Francesca Porfiri

Claude Parent: The Epistemological Shift from the Modernism

to the Metabolism

Alice Monacelli

The BIM Before the BIM, Nervi's Lesson in Parametric Among Architecture Structure and Construction

Andrea Grifò, Paolo Borin, and Andrea Giordano 


\title{
Raffaello Fagnoni and the School of Aeronautical Application-School of Air War in Florence Architecture of a Controversial and Damaged Past
}

\author{
Marco Ricciarini
}

\begin{abstract}
The growing and turbulent populism and the climate of renewed nationalism are today like a keloid on the skin, becoming a symbol of values that should be rejected. It is not possible to look at the architecture of Raffaello Fagnoni's School of Aeronautical Application-School of Air Warfare, which also clearly affirms the traces of its past, without noticing its beauty. The School is one of the most relevant examples of Italian rationalism, which emerged ten years later than the rest of Europe, from the impetus of very young architects from the Milan Polytechnic. A "hidden" architecture of the city of exceptional value, hermetic in its need to defend itself from the outside, but of extraordinary beauty within the limits of its intimacy. An architectural complex of the fascist period for which, from the collaboration between the Department of Architecture of the University of Florence and the Institute of Aeronautical Military Sciences of the Italian Air Force, a research and documentation path was started, to investigate the historical value that this architecture of the thirties has by now unquestionably assumed. Through an accurate survey campaign with digital instruments, the research project analyzes the most famous work of Raffello Fagnoni, designed at the end of 1936, begun to build in 1937 to be completed only nine months later, in March 1938 [1]. The documentation of the work of the avantgarde movement has highlighted its development halfway between the logical and innovative language of the great European architects and the tradition of Italian classicism, enriching this information database with updated digital drawings. Italian architecture in the period between the two great wars was among the most active at the level of cultural experimentation, favored by the multiple constructive perspectives of the regime, encouraged by the innumerable commissions, by the requests of the privileged political hierarchies, and by Mussolini himself. Architecture on several occasions was a propaganda tool of the progressive totalitarian vocation of the fascist regime. A movement promoting artistic styles that were political and ethical but also of narration and representation of historical time, which redesigned the past limits, the future horizons, and the present borders of the nascent Fascist era. The project of the Air War school was born in this specific cultural area, of using architecture as a powerful means of conquering the masses, on which political success was based.
\end{abstract}

\footnotetext{
M. Ricciarini $(\varangle)$

Department of the University of Florence, 50122 Firenze, FI, Italy

e-mail: marco.ricciarini@unifi.it

(C) The Author(s), under exclusive license to Springer Nature Switzerland AG 2022

C. Bartolomei et al. (eds.), Digital Modernism Heritage Lexicon, Springer Tracts

in Civil Engineering, https://doi.org/10.1007/978-3-030-76239-1_54
} 
Convincing the people of being safe under a strong leader and at the same time making Italy a great nation was the idea that moved the system.

Keywords Raffello Fagnoni · Florence Air War School • Italian rationalist architecture

\section{Introduction to Totality Architecture}

The changed political and social conditions, that arose after the end of the First World War, marked by the avant-garde ideal ferment of the futurists and the growing political movement inspired by Mussolini's socialism, will influence, a few years later, the new generation of architects formed in the conviction of a search for a formalism and an architectural aesthetic understood as a political and social battle [2].

Once Mussolini's power has settled, there will be the overbearing propaganda work of the regime, supported by a continuous urban architectural development of the country. The many intertwining, that characterized the complex events of Italian architecture between the two great wars, determined one of the periods of greatest development of cities and architecture, resulting precisely from the exchange of a continuous confrontation between the eclecticism of intellectuals and the affirmation of the progressive political ideologism of fascism [3].

It thus happens that what is generically defined as Fascist architecture, understood as the architectural urban construction production of the twenty years, derives in part from numerous architecture competitions promoted by the regime. Precisely these are the opportunity for exchange, comparison, and stimulation for the young architects of the time [4].

The intention on the part of the political power to unify the nation, to celebrate its image in the name of modernity will be determined by the dynamic and efficient public works investment program implemented by the regime. Architectural research thus diversifies into controversy to define architecture as a state art. This is interpreted by intellectuals and architects as a synthesis and formal expression of political content characterizing a style and image of architecture for the nation and the regime [5].

The elements of the classical tradition combined with the rationality of formal choices represent the compromise adopted by Piacentini, a very active architect of the regime. With his activity he will be able to make the formal dictates of neoclassicism his own, introducing a new architectural language to interpret the new mediation needs between classical spirit and modern attitude. The desire to express the dimension of the fascist state is manifested by his original style, marked by a distinctly eclectic imprint despite the search for the monumentality typical of the aesthetic trends of the time [6].

Midway synthesis with the classicism of the Novecento group (Giovanni Muzio, Emilio Lancia, Gio Ponti etc.) and the rationalism of Group 7 and MIAR of Giuseppe Terragni, Giuseppe Pagano, Adalberto Libera etc. [7]. 


\section{Rationalist Architecture in Florence}

Eternally young, typical representation of the way of life and existential style of the ruler of that time, absorbed in its beauty hides the Aeronautical Application School, today the Institute of Aeronautical Military Sciences. The Air War School for the Florentines is one of the three most significant examples of Italian rationalist architecture, designed by the architect Raffello Fagnoni in 1937 and built-in 1938. A work that together with the Stadium built by Pier Luigi Nervi in 1931 and the Santa Maria Novella station, was built by the Tuscan group led by Giovanni Michelucci in 1935 , will be destined to remain as a testimony of twentieth-century architecture [8].

\subsection{Raffaello Fagnoni}

Graduated in Rome from the Higher School of Architecture in 1924, Fagnoni returned to Florence and founded the Florentine section of the fascist architects' union, becoming a promoter, from 1926, of the Royal Higher School of Architecture in Florence.

In his works, critics have recognized an attempt to detach themselves from the furrow dug by Giovanni Michelucci within the so-called Tuscan School. Fagnoni divides his interest between European proto-nationalist architecture and local tradition: its structures derive from a logical analysis of functions, but do not remain disjointed like the models of rationalism, rather forming compact blocks, following the best tradition of Italian architecture [9].

\subsection{The Scuola di Guerra Aerea}

The Scuola di Guerra Aerea is located in Florence between dell' Aeronautica Street and del Barco Street.

Known as the School of Aeronautics, today it houses the Giulio Dohuet Military Air Force School (upper secondary education) and the Institute of Aeronautical Military Sciences (university training). 


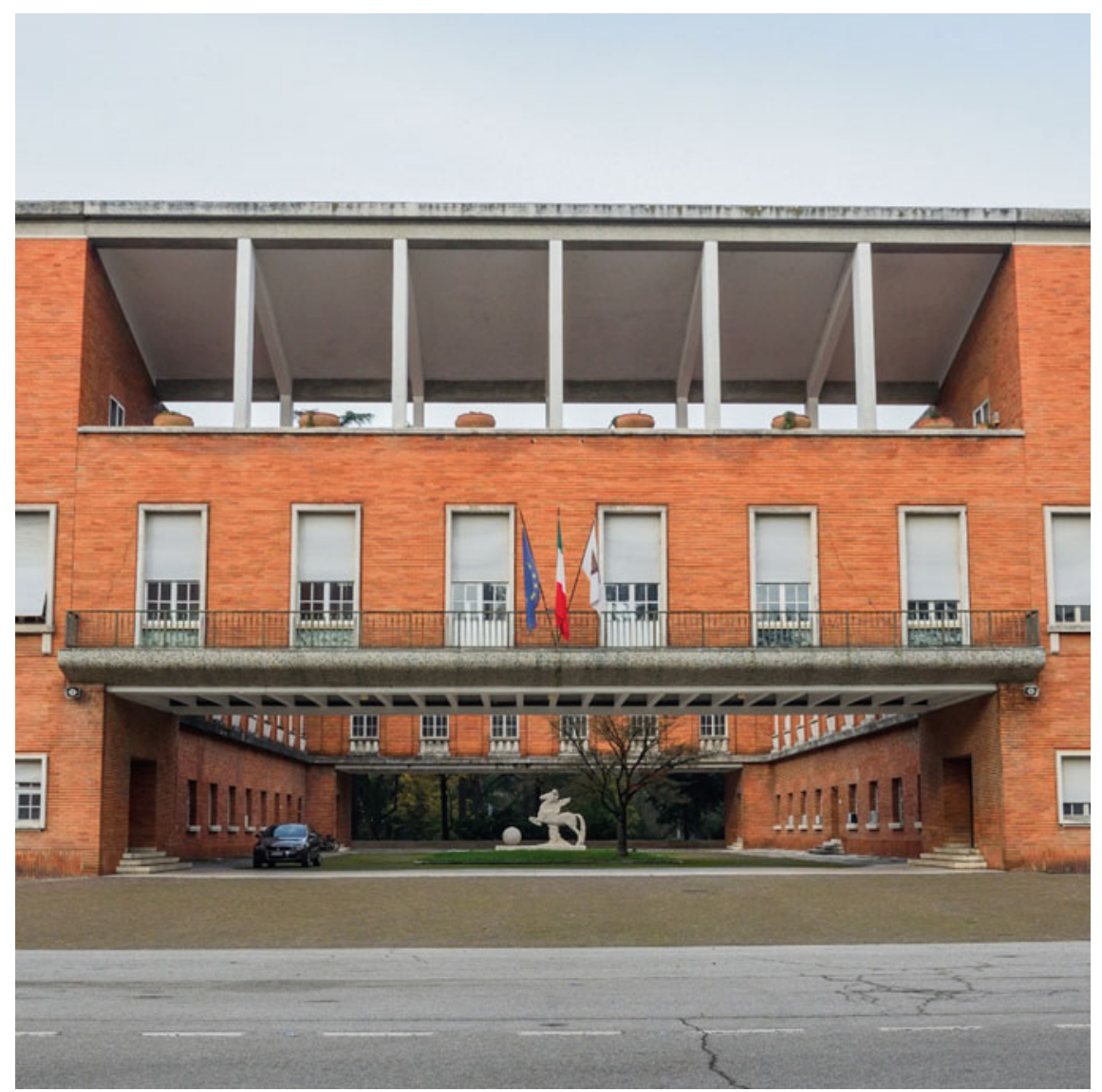

Raffaello Fagnoni, who designed it in 1936-37, left with it a significant example of rationalist architecture, preserved excellently both in the exterior and in the interior, with most of the original furnishings still being preserved [10].

The complex is within the Cascine Park in Florence, a context of landscape value. Each building that is part of the complex with its volume seems to find its place, blending into the park itself: the citadel thus has a natural protection in the surrounding wall, that runs all around and in the tall trees.

The School consists of a series of buildings arranged along two main axes and which are merged by the architect by function. The body of the official accommodation and health and sports equipment is in the southwestern end and along the transverse axis; in the center, there is the entrance, with a curved guardhouse; to the east, we find the school building and its classrooms and finally, to the north end, there are all the services and the barracks [11].

In the ideal heart of the military citadel, at the intersection of the two axes, in a barycentric position, is the body of the command. The architect then deliberately 
kept a large space in the western portion of the lot, coinciding with the layout of the ancient arboretum.

Symmetries and asymmetries carefully studied by Fagnoni give the complex an image of great monumentality. An essential architecture characterizes all the buildings which, with greater or lesser emphasis, offer references to contemporary European architectural culture as well as to the Mediterranean and classicism of the Italian experience that Fagnoni has expressly recognized [12].

The pure geometric volumes, which have a predominantly horizontal development and flat roof, have the red brick facing of the Valdarno on the outside; they offer various effects in correspondence of the openings and reflect an extremely accurate design. Instead, white travertine was used, which stands out against the red of the terracotta, for the decorative frames, window sills, stairways, and other details [13].

The only exception is the gym and swimming pool building, completely plastered with white lime. The result consists of a complex of buildings with homogeneity and harmony, while each maintaining a specific architectural character with different modular and overlapping games.

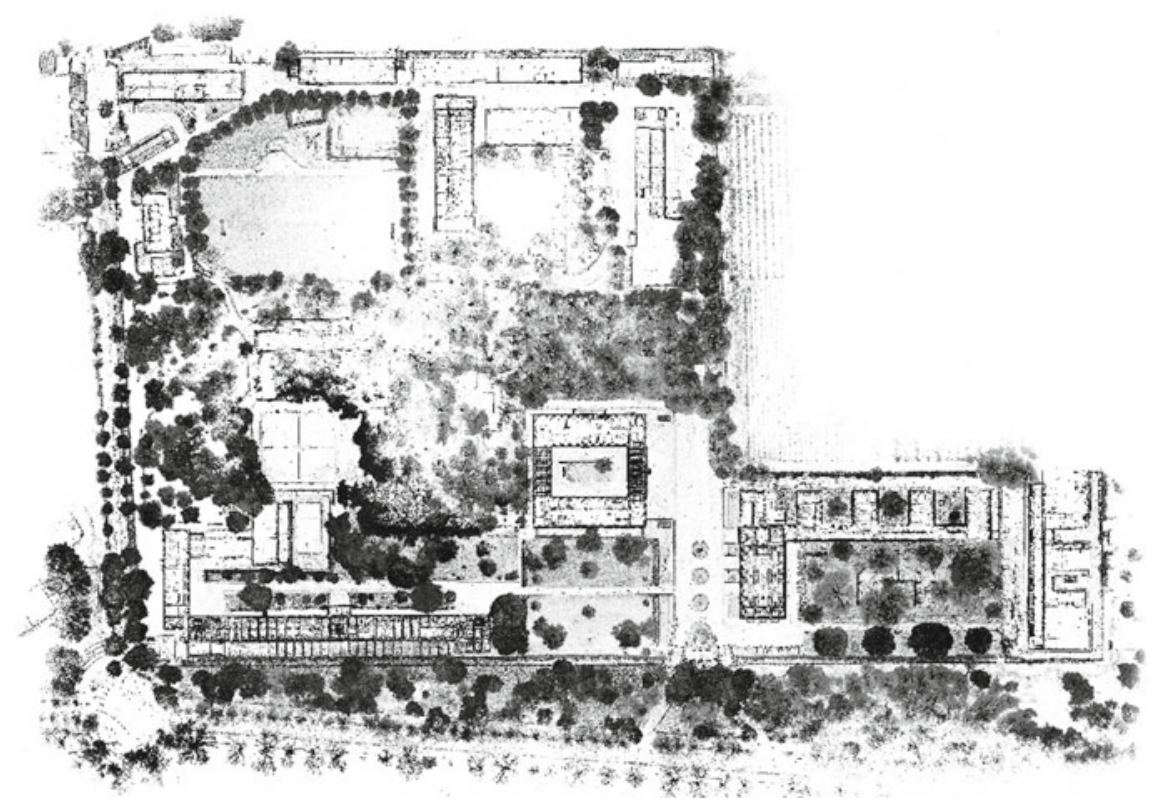




\subsection{The Arboretum}

Dating back to 1914, the arboretum was spread over an original area of over 2.5 ha: it was incorporated into the complex at the time of construction.

The collection was created to study the possibility of acclimatization of different exotic species, divided into two sections: the laureate, with species from Asia, Europe, America, Australia, and the castanetum with other species from Asia, Europe, America. They were protected by a windbreak of cypresses (Arizonica and Lusitanica) with a nursery in the center [14].

The surface of the arboretum then contracted to 2.20 ha as it was neglected during the Second World War. The plants were no longer separated by area of origin and the creation of service roads and sports facilities led to the suppression of a certain number; another damage was caused due to the use of the area as a garage for war vehicles. Finally, irrigation was also modified, and with the Florence flood in 1966 other specimens were lost in addition to all the existing labeling.

In 1967, the experimental forestry station was transformed into an Experimental Institute for forestry-based in Arezzo and an operational section in the Florence Arboretum. It was only in 1984 that all the plants present were reclassified and 10 years later a definitive labeling, including electronic ones, was developed.

\subsection{The Criticism}

The School did not have a univocal and decisive criticism, but rather varied and alternating: phases of enthusiasm and total silence followed one another and phases of rethinking and critical review, and this fate is typical of several buildings designed and built in the years of Fascism.

Initially, right from the earliest stages of construction, Fagnoni's work sparked strong interest and unanimously received positive opinions, in particular from Marcello Piacentini - as already mentioned, the absolute protagonist on the Italian architecture scene in the thirty years 1910/1940. The complex was particularly praised both because it was built quickly and because it was perfect for the contingency of the period and the architectural gracefulness of some buildings, such as the command pavilion, for example.

Indeed, Fagnoni managed to achieve a synthesis between the Tuscan tradition (Michelozzo, Buontalenti) and the modern architectural language and this without losing the indispensable requisites of monumentality and severity. And it was precisely this perfectly successful synthesis that earned him the greatest appreciation for his work. 
When the dictatorship fell, a deafening silence also fell on the complex, with the exception, however, of Muratori who in 1949 called it "immense and true work" with the great merit of having opposed the cerebral and mechanical rationalism of foreign and local artifacts.

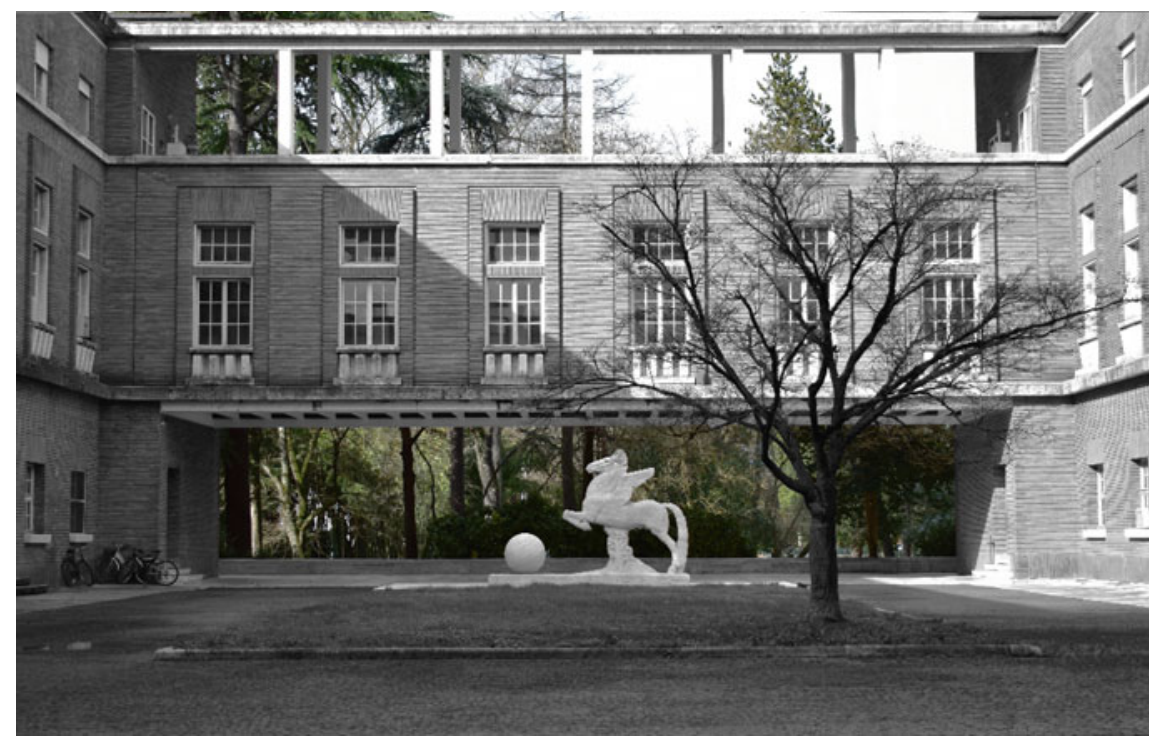

It will take another twenty years or so to find an enthusiastic re-evaluation of the work by Koning who in 1968 praised Fagnoni for having stayed away from monumental excesses, anchored to distributive and planimetric rationality — contrary to Libera, Quaroni, Fugini, and Pollini which in the Eur buildings returned to the arches and columns.

Because of the World War Fagnoni's work was published in American magazines from its inception, presented as one of the rare examples that did not fall under the rhetoric of the Armed Forces on architecture. And it was always Koening who emphasized how this earned her an international rather than a national fortune.

Koening's marked appreciation from the end of the sixties of the last century helped to direct the criticism towards positive judgments.

The skillful play of the relationship between solids and voids has already been emphasized since the mid-1980s, and a monograph dedicated to the School was printed in 1988, where various interventions concur in its architectural knowledge. 
Gurrieri considers it, together with the station and the stadium in Florence, one of the three architectures not underlying the rhetoric of Piacenza; Savi appreciates the articulation of the urban and architectural layout, which means that the complex can well be characterized as a city of the air, similar to the typically fascist cities, but with a completely different compactness. Only Cresti expresses his disappointment by opposing the positive revaluations, as he believes-as Cozzi later confirmed in 1991 - that formally and stylistically the complex of the Air War School has not overcome the impossible combination between the rigid German models and the Tuscan elements and Mediterranean [15].

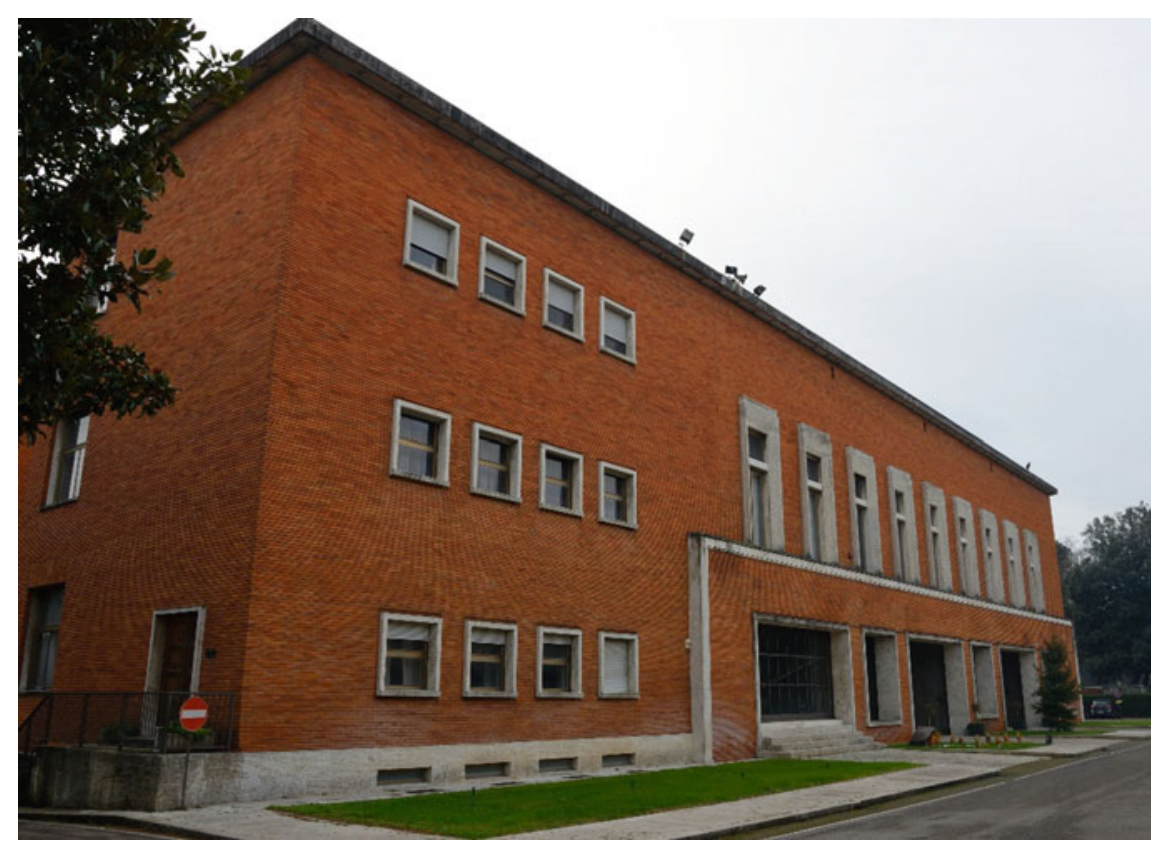




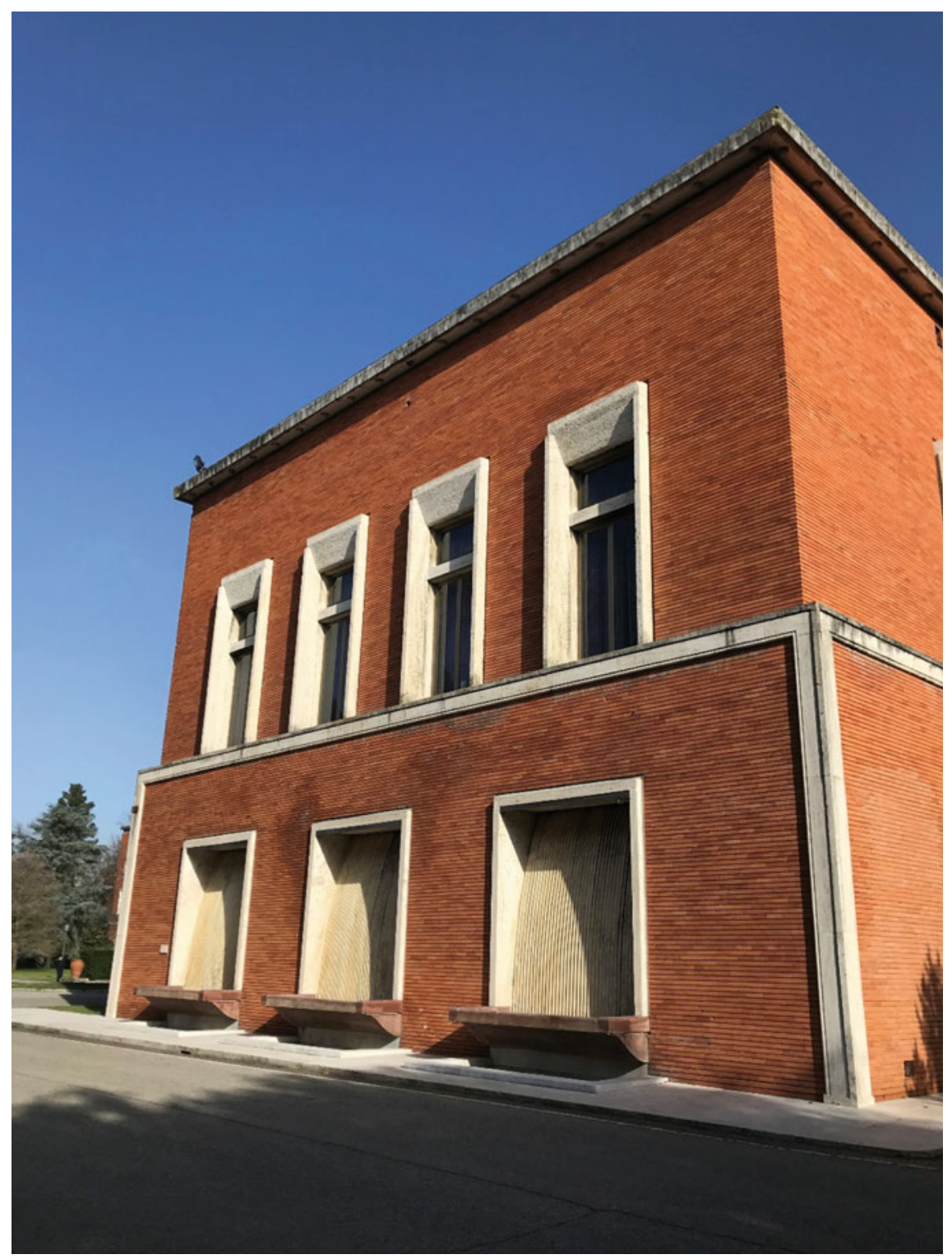




\section{Digital for Architectural Analysis}

The Survey Laboratory of the Department of Architecture of the University of Florence, in collaboration with the Air Force, in 2018 launched scientific research related to the field of architectural survey to define the typological and volumetric complexities of the complex. The acquisition of the morphological characteristics of the external environments, aimed at the analysis and digital representation of the decorative technological details, of one of the most important works of modern architecture in Florence, is now followed in a more ambitious project for the management of the architecture and installations.

Identifying, documenting, and preserving the memory of the past to give value to the future of the architectural heritage is an operation that is established starting from a major project that allows you to acquire the architectural figuration and the qualities of the object that you intend to enhance.

\subsection{Criticalities and Resolutions}

The problem of representation, that is posed to the detector, is not so much in the presentation of the object as such, but rather in the ability to represent how that object is understood through the interpretation of cognitive processes, that allow its correct understanding, within the context, giving it the right meaning and value.

One of the purposes of the research carried out on the School of Air Warfare was the development of methodologies of use for shooting and restitution technologies, necessary for the documentation of the architecture, which were able first of all to investigate the modernist lexicon of architecture. The design of the real becomes the adequate technical support for the planning of executive restoration interventions and the tool for knowing in depth the materiality and formalisms of architecture.

The character of a major project is preparatory to the definitions of actions necessary to protect, preserve or enhance an architectural work, and refers to all those activities that a subject applies to define the spatial-dimensional characteristics of an object and to all the data characterizing the architecture investigated, from the material ones to the functional ones.

The survey carried out on the complex of the Air War School therefore constituted a fundamental knowledge base for the exercise of critical and interpretative activities of architecture, the urban context, and the environment and which defined its characteristics and quality.

One of the salient aspects of the research was the definition of the accuracy, tolerances, techniques, methods, and outputs of the survey. 

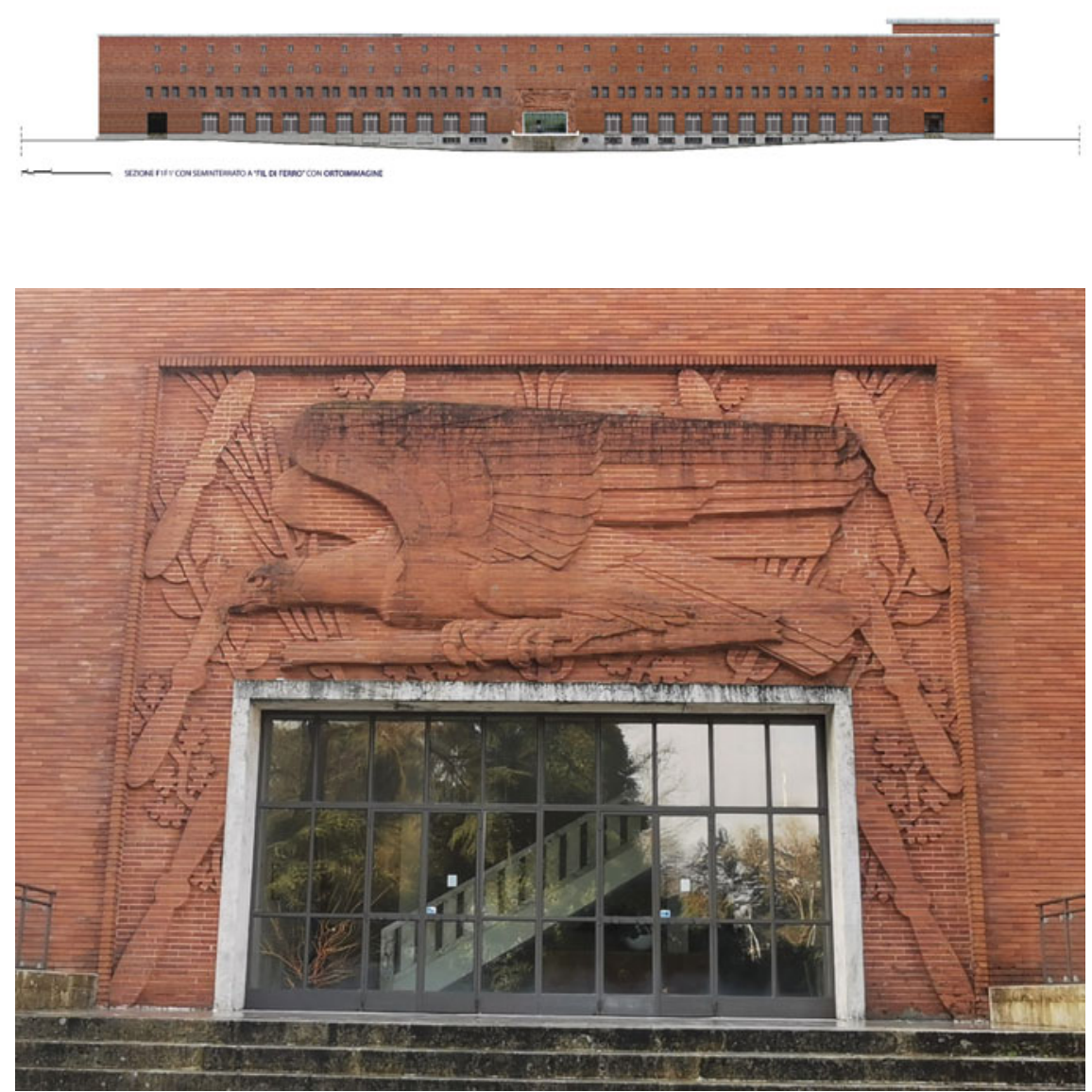

\subsection{Methodology Applied}

The definition of the most suitable method and tools for the acquisition and consequent return of a digital model of the aeronautics training complex in Florence was an approach taken into special consideration. For this purpose, the work was organized starting from a cognitive analysis of the entire architectural complex, in a certain sense to enter into symbiosis with a place that, given its inaccessibility, as a military structure, gives rise to a certain suggestion considered the extreme rigor and austerity of the environment in contrast to the external Cascine park. 
Another goal, resulting from the two-dimensional digital representation, was to map all the buildings that make up the entire complex and all the external environments, to obtain a three-dimensional model of the work.

From the analysis of the complex and buildings of the R. Aeronautics Application School, it is clear that the school's activity orders are defined by the different buildings built and their location conditioned by the general anti-aircraft defense rules of the time. This provided for an appropriate distance between one building and another and that, as far as possible, the buildings should be placed side by side with the highest vegetation.

The definition of these parameters unquestionably conditioned the planning of the complex, but did not prevent Fagnoni from conceiving a work with the articulation and the formal variety of the buildings, although they are all attributable to simple volumetric forms with a markedly rationalist imprint. The emergent character is that of the empty-to-full relationship of the volumes of the brick wall mass and the demarcation lines obtained with travertine frames.

The work does not take into consideration the internal analysis of the buildings, but focuses on the study of the superficial apparatuses of the buildings, the elevated structures, the decorative systems of the facades of the buildings, the morphological study of the architectural complex, and the layout of green spaces in particular of the Arboretum of the Royal Forestry Experimentation Station.

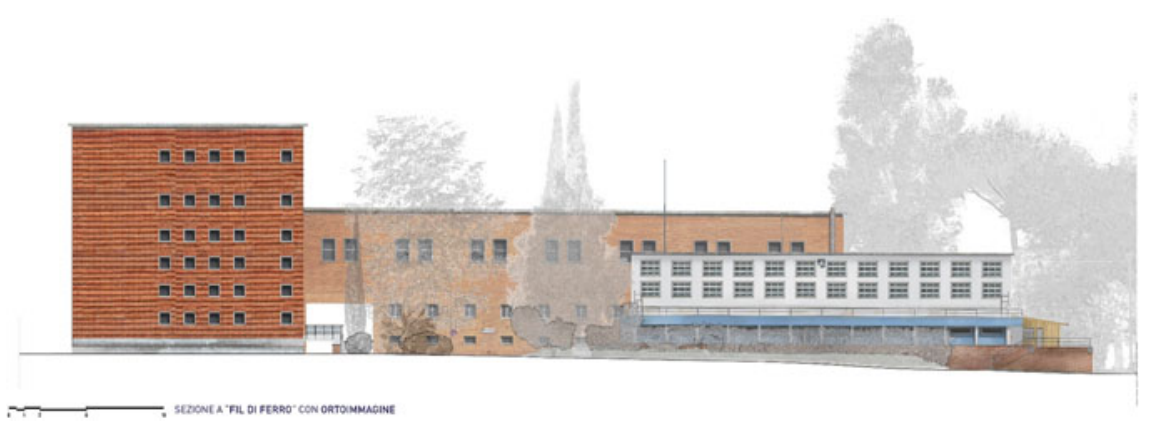

\subsection{The Study of Volumes}

The buildings were then analyzed from a typological, geometric point of view and the quality of surface and material properties. The volumes, whose design was influenced by the recommendations to maintain a solution of continuity with the other complexes built for the Aeronautics, are typologically diversified by position and function, characterized by different geometries and characterized by the terracotta cladding, except for the gym block.

During the survey campaign, for a correct reading of the modern architectural expression of the entire complex, it was decided to use the latest generation laser 
scanner survey techniques, for the production of 3D point clouds equipped with sufficient accuracy to carry out a suitable reading of the morphology of the monument. The point clouds thus obtained were then recorded by the Survey Laboratory of the Department of Architecture, to obtain a morphometric model of the architectural complex. The management of the total point cloud made it possible to create the sections suitable for performing the two-dimensional graphic returns of the product. An accurate 1:50 scale rendering of the prospectus sections provided the opportunity to identify:

a. the formal and material characteristics of the building;

b. the recurrence of the formal and material peculiarities identified;

c. the relationship with the context.

The survey found the state of conservation of the command and administration buildings, teaching buildings, student residences and military sports training and services and the armed guard, their formal and material peculiarities.

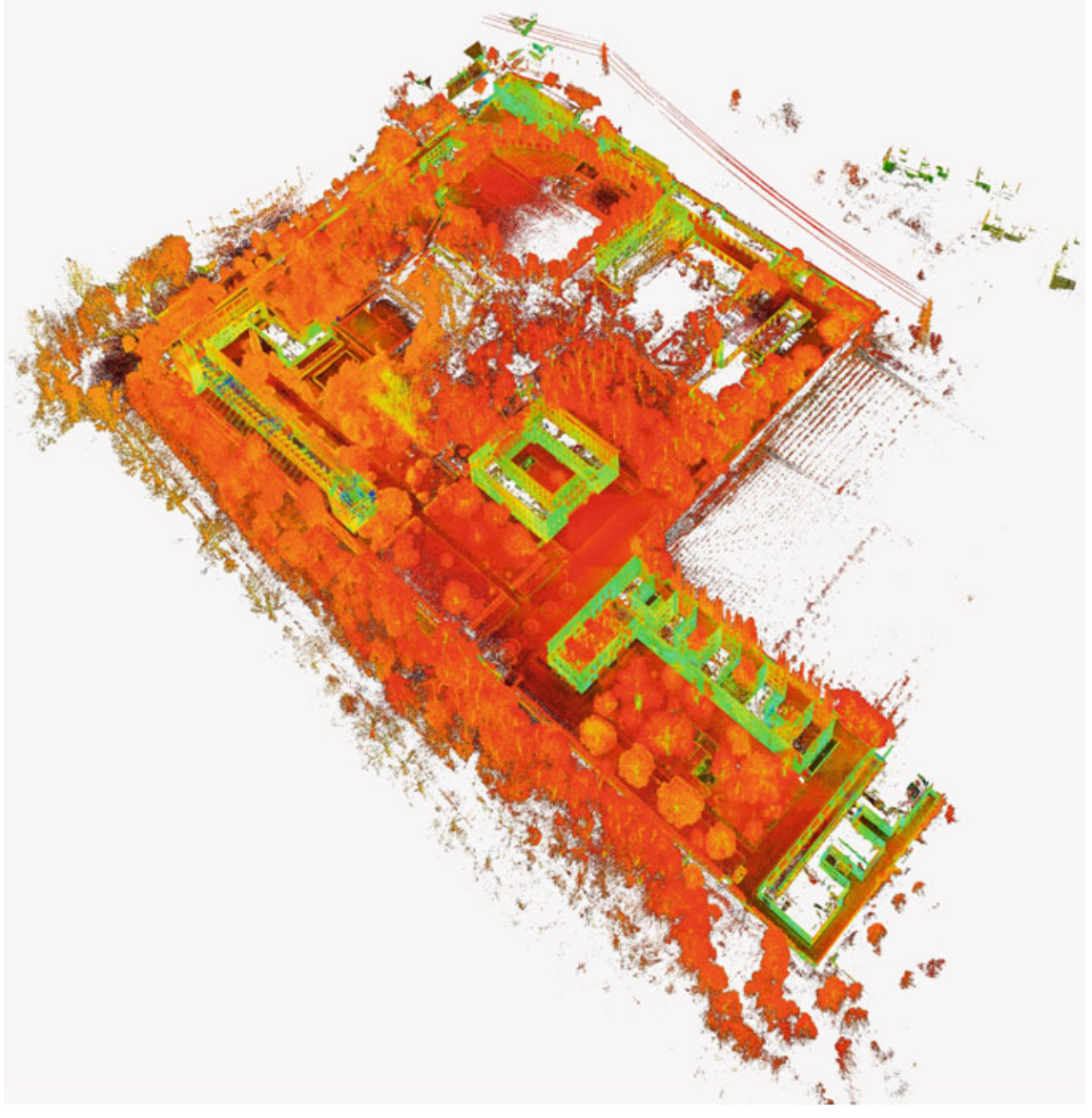


The study shows that the brick cladding has determined an unusually good state of conservation of the buildings that make up the Military Institute, considering that over eighty years have passed since its construction and that during this period no significant restoration interventions were carried out.

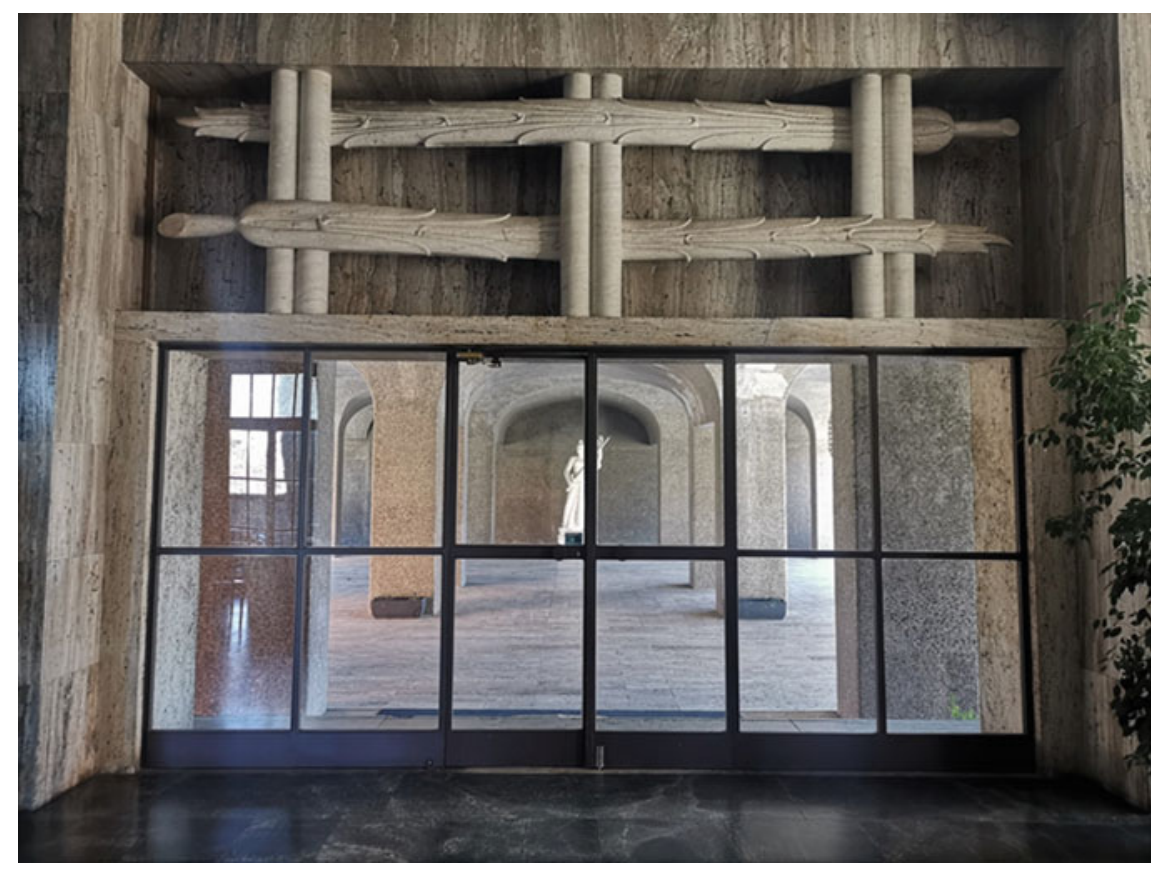

\section{Representation as a Knowledge Tool}

The representation of the elevations of the various buildings obtained from the processing of the data acquired from the digital survey operations using the Laser Scanner and the photogrammetric survey has allowed a reflection on the nature of the project, in which one perceives the constant search by Fagnoni for an architecture that is the fruit of mediation between right measure and reinterpretation of the expression of the modern international movement.

The photorealistic representation of the Air War School, created using both the data obtained from the photogrammetric survey and laser data, guarantees the reading of the architect's architecture aimed at demonstrating the clarity of the general setting and the rationality of the functional organization of modern language in line with the new spirit of the era. 
The volume of the buildings is defined by the massiveness of the brick walls and the crowning of the eaves in white Duralbo concrete, while travertine is used to mark only the most important buildings with squares and frames.

In the building of the Command, the use of marble serves as a decorative element, the frames on the windows mark the relationship between full and empty of the facade.

The plan of the military complex, defined by the Air Force, provides for the arrangement of the buildings parallel to the limit of the Cascine side, taken as one of the two reference axes on which the whole project is set. The urban project establishes a small cardo documents system with the same orientation as that of Roman origin which can be traced on the Florentine plain.

The analysis process for understanding the complex also involved the documentation, the naturalistic system of the arboretum, understood as a group of plant units, to digitally catalog the trees that compose it. The study of greenery has taken on the descriptive values useful aspects for conservation, management, and control.

\section{Conclusions}

The production of representative material of the aerial warfare school, consisting of a rich repertoire of images and information, was useful for promoting this hidden architecture of Florence and relating it to reality by making it "go beyond the spatial and temporal boundary" in which is contextualized.

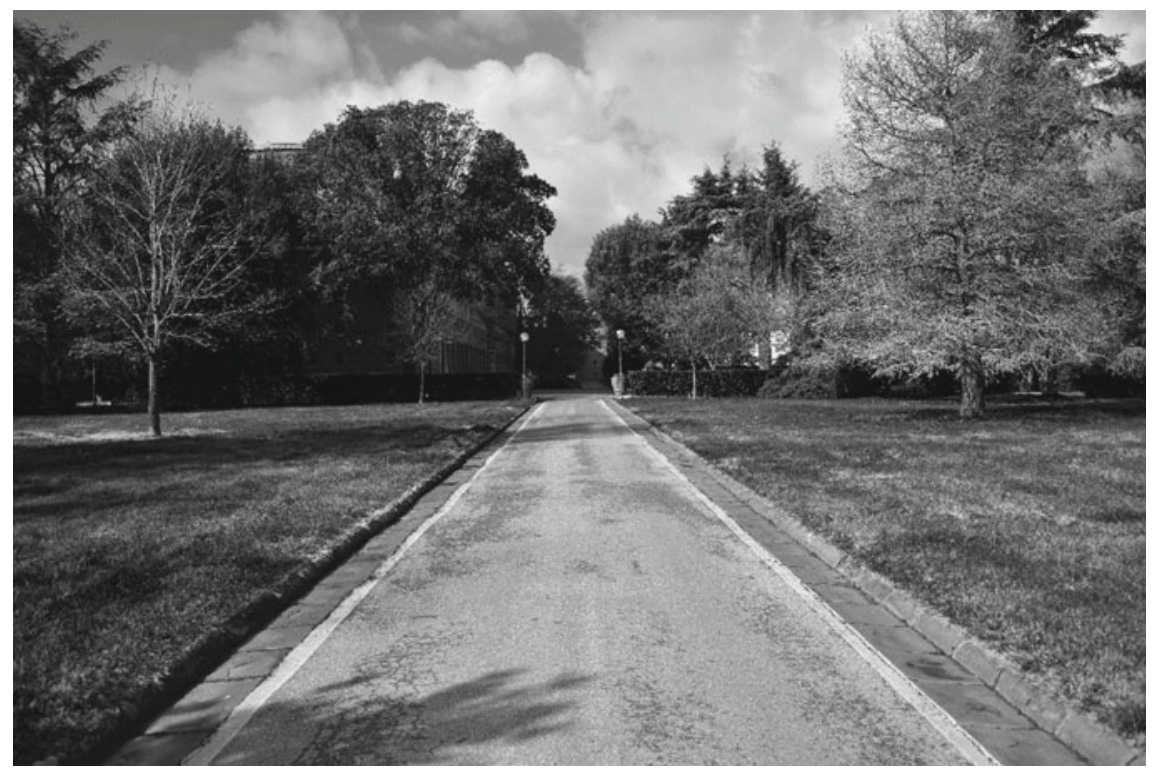


Acknowledgements Photographs and digital representations are all property of the author of the text. We thank the students of the course drawing workshop of the academic year 2017/2018 for the support provided in the graphic returns of the acquired data.

\section{References}

1. La scuola di Applicazione Aeronautica (1937) In Firenze-Rassegna del Comune, Firenze, p 279

2. Ciucci G, Dal Co F (1990) Architettura Italiana del '900. Atlante. Electa, Milano

3. Poretti S (2008) Modernismi italiani: architettura e costruzione nel Novecento. Gangemi, Roma

4. Ciucci G (2002) Gli architetti e il fascismo: architettura e città 1922-1944. G. Einaudi, Torino

5. Argan GC, Bonito Oliva A (2002) L'arte Moderna 1770-1990. L'arte oltre il Duemila. Sansoni, Firenze

6. Brunetti F (1993) Architetti e fascismo/Fabrizio Brunetti. Alinea, Firenze

7. Benevolo L (1985) L'ultimo capitolo dell' architettura moderna. Laterza, Roma Bari

8. Pagani C (1984) Tre architetture degli anni trenta a Firenze. Società delle belle arti - circolo degli artisti - "casa diDante" - Firenze, pp 113-134

9. Koenig GK (1968) Architettura in Toscana, 1931-1968. Eri, Torino

10. Fagnoni R (1938) La scuola di Applicazione per la R. Aeronautica a Firenze. In "Architettura", Roma, p 331

11. Fagnoni R (1988) Architettura della scuola di Applicazione Aeronautica di Firenze. Electa, Firenze

12. Ranisi M (1981) La scuola di Applicazione dell'Aeronautica Militare a Firenze. In Edlizia Militare, Roma, anno II, p 27

13. Di Camillo C, Di Gangi F, Lanzilli A (2018) Aeronautica Militare a Firenze legame di arte e cultura. Percorso storico architettonico tra le mura dell'istituto di Scienzae Militari Aeronautiche. Edizioni Polistampa

14. Podestà G (2006) Istituto di Scienze Militari Aeronautiche. L'Architettura di Raffaello Fagnoni per la Scuola di Applicazione Aeronautica. Scuola di Guerra Aerea. Firenze. Polistampa, Firenze

15. Fanelli G, Gargani R (2004) Storia dell' architettura contemporanea: spazio, struttura, involucro. GLF editori Laterza, Roma Bari 